\title{
Division of labor: multiple and specialized controls of vegetative growth and development in a poplar tree
}

\author{
Victor Busov ${ }^{1 *}$, Yiru Chen ${ }^{1}$, Jiqin Gou ${ }^{1}$, Steven Strauss ${ }^{2}$, Yordan Yordanov ${ }^{1}$, Christine Zawaski ${ }^{1}$ \\ From IUFRO Tree Biotechnology Conference 2011: From Genomes to Integration and Delivery \\ Arraial d'Ajuda, Bahia, Brazil. 26 June - 2 July 2011
}

Plants size, shape and adaptability are determined in large by their capacity to sustain, spur, redirect or arrest localized and whole-plant growth. We show that GA signaling and metabolism determines the level and extent of shoot and root growth. Increase of GA concentrations or signaling leads to increased shoot growth but suppresses root development. These GA-related responses are underpinned by sets of highly specialized in their functions enzymes and signaling factors and cross-talk with other hormonal pathways. The differential effects of GA on root and shoot growth and development are likely associated with a regulatory mechanism responding to optimum and stress conditions. Ongoing work in the laboratory employs genomics and genetics approaches to more thoroughly understand poplar growth and development under stress conditions including nitrogen and water limitations. We use genetic networks analysis and forward genetics approaches to identify key regulators of poplar roots response to stress. Besides overall growth, trees show incredible repertoire of spatiotemporal regulation of growth in relation to control of organ size, growth periodicity and tropic responses. We have identified and characterized novel regulators of these processes in poplar.
*Correspondence: vbusov@mtu.edu

${ }^{1}$ Michigan Technological University, USA

Full list of author information is available at the end of the article
Author details

${ }^{1}$ Michigan Technological University, USA. ${ }^{2}$ Oregon State University, USA.

Published: 13 September 2011

doi:10.1186/1753-6561-5-S7-110

Cite this article as: Busov et al.: Division of labor: multiple and

specialized controls of vegetative growth and development in a poplar tree. BMC Proceedings 2011 5(Suppl 7):110.
Submit your next manuscript to BioMed Central and take full advantage of:

- Convenient online submission

- Thorough peer review

- No space constraints or color figure charges

- Immediate publication on acceptance

- Inclusion in PubMed, CAS, Scopus and Google Scholar

- Research which is freely available for redistribution

Submit your manuscript at www.biomedcentral.com/submit
Ciomed Central

(c) 2011 Busov et al; licensee BioMed Central Ltd. This is an open access article distributed under the terms of the Creative Commons 